\title{
Recruitment And Use Of Child Soldiers In Afghanistan: Cultural Traits As Pivotal Factor
}

\section{Ghulam Mohammad Qanet}

Public Law Department, Faculty of Law and Political Science, Herat University. Email: ghulammohammadqanet@gmail.com

\section{Mohammad Shekaib Alam}

Department of Political Science, International Islamic University Malaysia.

Email: ibnqj3@gmail.com

\section{Mohammad Naqib Ishan Jan}

Civil Law Department, Ahmad Ibrahim Kulliyyah of Laws, I nternational Islamic University Malaysia.

Email: naqib@iium.edu.my

\begin{abstract}
This paper explores the cultural values that prevailed in Afghanistan to understand the recruitment and use of underage soldiers in the long-lasting armed conflict while comparing the existing domestic and international law. The study analyzed the effect of the traditions of Afghans on child soldiering. The method was doctrinal, and therefore, the collected and analyzed data was qualitative. The analysis was thematical, where each related idea was subjected to review and evaluation. The research found that since time immemorial, the Afghan culture traditions were conducive to underage soldiering for various reasons, including peace and justice where male and female child warriors are treated as heroes, perhaps more than any other member of the Afghan society. Due to the stated reasonings, the study established that more underage soldiers were used and recruited during the period of the British Empire, Soviet invasion of Afghanistan, and the civil war that caused the Taliban and Northern Alliance to resume control and in the post 9/11 phase of armed conflict in Afghanistan irrespective of domestic and international law that prohibited the recruitment and use of underage soldiers as it violated their basic fundamental rights of childhood.
\end{abstract}


Keywords: Recruitment of Child Soldiers, Use of Child Soldiers, Afghan Culture, Honour, Hospitality, Revenge.

\begin{abstract}
Abstrak
Artikel ini mengeksplorasi nilai-nilai budaya yang berlaku di Afghanistan untuk memahami perekrutan dan penggunaan tentara di bawah umur dalam konflik bersenjata yang berlangsung lama sambil membandingkan hukum domestik dan internasional yang ada. Studi ini menganalisis pengaruh tradisi Afghanistan pada tentara anak. Metodenya bersifat doktrinal, sehingga data yang dikumpulkan dan dianalisis bersifat kualitatif. Analisisnya bersifat tematis, di mana setiap gagasan yang terkait menjadi sasaran tinjauan dan evaluasi. Penelitian tersebut menemukan bahwa sejak dahulu kala, tradisi budaya Afghanistan kondusif untuk tentara di bawah umur karena berbagai alasan, termasuk perdamaian dan keadilan di mana pejuang anak laki-laki dan perempuan diperlakukan sebagai pahlawan, mungkin lebih dari anggota masyarakat Afghanistan lainnya. Karena alasan yang disebutkan, penelitian ini menetapkan bahwa lebih banyak tentara di bawah umur digunakan dan direkrut selama periode Kerajaan Inggris, invasi Soviet ke Afghanistan, dan perang saudara yang menyebabkan Taliban dan Aliansi Utara untuk melanjutkan kontrol dan di pos 9/ 11 fase konflik bersenjata di Afghanistan terlepas dari hukum domestik dan internasional yang melarang perekrutan dan penggunaan tentara di bawah umur karena melanggar hak-hak dasar dasar mereka di masa kanak-kanak.
\end{abstract}

Kata kunci: Rekrutmen Prajurit Anak, Penggunaan Prajurit Anak, Budaya Afghanistan, Kehormatan, Keramahan, Balas Dendam.

\section{INTRODUCTION}

This study focuses on and addresses the recruitment and use of child soldiers in Afghan culture. The research on child recruitment suggests that scrutiny of the Afghan culture provides a satisfactory answer without reference to the implementation process, country's history, culture, and custom (Norway: Landinfo, 2017). The modern Afghan history of struggle against powerful foreign invaders has undoubtedly contributed to the readiness of Afghan people to take to arms and fight for their dignity 
and freedom (Saikal, 2004). The heroic struggle of the Afghan people and victories against the British Imperial Army (M., 2015) ${ }^{1}$ and the Soviets have been recorded in the memory of every living Afghan and on paper by the Afghan intellectuals. They have been shared with the new generation orally and are being passed out to them through books in institutions of formal learning (Dowling, 2015). Both of these sources, the orally-transmitted epics, and scholarly-penned historical accounts have contributed to the image of undefeated and undefeatable Afghan hero, ever ready to rise against oppression, tyranny, and assault on its dignity and honor, to defend its corpus from anyone who might dare to threaten these values and opt to go down the spiral of the armed conflict (Hassan, 2006). These circumstances ought to be considered to grasp the discrepancy between the legal ideal's mechanisms against child soldiering and realities on the ground. Hence, seen from the perspective of culture,

1 Towards the end of the $19^{\text {th }}$ century, the British army had a regulation that boys as young as fourteen could enlist into the army. Thus, during the Second Anglo-Afghan War (1878$1880)$ and the Boer Wars (1880-1881; 1899-1902), there were around 3,000 boys serving in the British army. child soldiering is not considered a violation of norm and custom, and as such, it is not deemed a reprehensible practice. The issue is, however, not innocuous in other fields of knowledge, such as law. Within the perspective of law, both national (Qanet \& Jan, 2019) and international (Qanet1 \& Jan1, 2019); (Steinl, 2017); (Ann, Robinson, \& I'Anson, 2018); (Jha, 2018); (Vautravers, 2008) child soldiering is studied to the extent it violates legal standards and particular laws (Christine, 2007).

Child soldiers, their recruitment and use are complex. Similarly, the interrelated cluster of terms requires a closer investigation as separate terms and expressions when used together. When international treaties and local legal laws of Afghanistan and practice are considered, no uniform, universally accepted definition of a child is observed (Elisabeth \& Elbert, 2010). The Afghan culture does have a clear view of what a child is, but when this view is placed in the socio-historical context, the clarity becomes somewhat diluted. The terms recruitment and use of child soldiers are perhaps less complex, particularly if seen from the perspective of recent international treaties and documents (Qanet1 \& 
Jan1, 2019). Child soldiers are used in multiple capacities (Steinl, 2017), including as on high-ranking armed group soldiers, but their capacity or service do not affect their status (Achvarina \& Reich, 2006), since the latest treaties of international law and opinions of legal experts have clarified that all recruited child serving in the armed force or armed group in any capacity are uniformly treated as child soldiers (Qanet1 \& Jan1, 2019).

The problem of child combatant conscription and use in armed struggle in Afghanistan calls for consideration of two features relevant to the subject. The first feature is the position of Afghan culture and the second position of the domestic legal framework on the subject. The research has implied descriptive, comparative, analytical, and synthetic methods, including field techniques and archival research methods. The descriptive approach proved useful in analyzing numerous definitions of the key terms found in culture and Afghan national legal references. The comparative approach was necessary to compare the views of various cultural factors and juxtapose them with national sources, laws, and practices. The entire discussion has been made in four subtopics; the first offers a detailed perception and custom of recruitment and use of child soldiers in Afghan culture, secondly presents the understanding of adulthood and its responsibility in Afghan culture, thirdly deliberates factors that allowed and accepted child soldering in Afghanistan and lastly, it concludes the research.

\section{Recruitment and Use of Child Soldiers under Afghan Culture}

Any attempt at finding a conclusive link between a particular culture and violence, or more specifically, the propensity of underage persons to enlist as child soldiers, requires a great deal of research because the term culture comprises many aspects of a community. Yet, Afghanistan's recent past and the notion of masculinity prevalent among the Afghans are filled with violence and ever-readiness to protect one's dignity and sovereignty (Zyck, 2011; Fog, 2017). Afghanistan's long and eventful history has been a replete heroic struggle of its people for survival and self-determination (Zyck, 2011). In modern times, the Afghans had to fight against several powerful foreign invaders, i.e., mighty British, the Soviet 'Red Army' etc., where they emerged victorious, though with huge 
casualties (Angelo, 2005; Hassan, 2006; Fog, 2017).

The history of struggle against foreign invaders has certainly contributed to the readiness of Afghan people to take to arms and fight for their dignity and freedom (William, 2010; William B., 2012; Greenberg Research, Inc., 1999). All these turmoils have left an indelible mark on nearly two generations of the youth who have not seen a peaceful country, as the author puts it forward: "Today, Afghanistan is faced with the consequences of decades of violence, mass exodus, and displacements: it is insecure, intolerant of diversity of views, and home to nearly two generations that have grown up surrounded by conflict and war. Violent and aggressive behavior-particularly from young men-has become an accepted norm of Afghan society" (Ahmadi \& Stanikzai, 2018). The ideas summarized in the above quotation indicate the effects of long-lasting armed conflict on youth in Afghanistan. The underlying problem operates in a vicious circle, where protracted violence generates more negative traits and intolerance towards others (Ahmadi \& Stanikzai, 2018). This feature alone explains why there is a tendency towards violence in a country whose population is largely young or below the age limit for soldiering seen as an adult. To recap, an extended period of armed conflict triggers more dissatisfaction and serves as a cause of renewed armed conflict among the Afghan population (Ahmadi \& Stanikzai, 2018).

\section{Perception of Adulthood in Afghan Society}

The definition of a child or the period of childhood as opposed to the stages of adulthood in the major treaties of international law overemphasizes the chronological aspect of humanity without giving much room for other factors such as culture, religion, and a host of other aspects that shape our individual and social self (Dupree, 1980; Ewan \& Hatch, 1990; Aisling, 2013). This definition is based on premises relevant to the Western countries and societies where most young persons can comfortably live and rely on their parents and state welfare to satisfy their needs (Dupree, 1980). In contrast, an Afghan child from rural areas enters the adult world where great duties and responsibilities are associated with him directly from pre-adolescent years (Ahmadi W., 2008). A renowned Western scholar into the history and culture of Afghanistan observed that "Sub teen boys begin to assist their fathers 
in the fields, or, if nomadic, learn to ride, shoot, and herd. They can no longer play freely with their female counterparts. Childhood is over; adulthood begins. One major feature of child socialization in the Afghan non-urban society is that children have no adolescence, no transitional, educational period among their contemporaries away from their families to prepare them for the world they enter as adults. The young Afghan boy from 10 to 12 (or even younger) moves directly into an adult world" (Dupree, 1980) and is expected to assume the full responsibility as adults do (Andvig \& Gates, 2010).

Chronic persistence of war and the availability of combat weapons within most, if not all, families in Afghanistan have certainly affected the course of the childhood of at least two generations. Even before the beginning of the armed conflicts starting with the Soviet invasion of Afghanistan, many Afghans had the habit of carrying arms in some areas (Brett \& Specht, 2004). ${ }^{2}$ According to Dupree, when an average Western

2 All Afghani families have always had guns. From a long time before the recent wars, Afghans carried guns with themselves. Because Afghanistan has never been secure, child would get his first toy gun present by his father in Afghanistan, the child receives training in handling a real gun. This contrast, too, aids in understanding the gap between a child's perception within society and the time when they have presented toys or real weapons (Dupree, 1980).

Due to loyalty to family and concern for its survival, Afghan children and adolescents are also, in many instances, expected to aid in the financial needs of a household. This aspect has come about not only because of society's cultural norms and customs but also due to the synergic effect of long-lasting armed conflict, a devastated economy, and scarcity of funds, whether in the form of aid or investment. Thus, much before their eighteenth birthday, young boys can be seen as street sellers, artisans involved in carpet weaving and pursuing other traditional crafts that can be a source of income (Lee, 2009). The stated circumstances combined, cultural, economic, and political ones, force the Afghan boys to skip the stage of adolescence and leap into adulthood directly from childhood (Lee, 2009).

people had to be armed to keep and defend themselves. 
Factors Contributing to Normalize Child Soldiering in Afghan Culture

Being situated in the strategically important crossroads wedged between large nations, Afghanistan has long been the battleground of military campaigns and various efforts to assimilate its people and win their hearts and minds. Three major campaigns mentioned before in the modern history of Afghanistan have greatly impacted the culture and character of the Afghans (Monsutti, 2013). Apart from being the object of military campaigns and resultant battles for self-defense and protection of their sovereignty, some traditional customs of the Afghans also contributed to everreadiness to fight and defend their dignity and cultural identity. Two of these features that researchers and scholars have recognized in the history and culture of Afghanistan are honor and hospitality (Poulton, 2003).

The paramount importance of honor for the Afghans and how it can be brought into connection with the recruitment of the young and old to fight against alien forces is well illustrated by Poulton in an account that goes back to the mid- $15^{\text {th }}$ century (Poulton, 2003). According to the author, when
Sultan Muhammad Shah from Delhi tried to conquer one of the villages in Afghanistan, his forces met with ferocious resistance. Ultimately, the Sultan conquered the place and took an old and frail man named Malik Feroz as a prisoner. The Sultan and his guards then asked him to recognize the heads of the slain villagers who had been decapitated upon the conquest (Poulton, 2003). The older adult recognized all of them except one, whom he initially pretended not to know. When one of the Sultan's officers said that the unrecognized head was of the soldier who had fought bravely until his last breath and killed a dozen of Sultan's soldiers, the captive Malik Feroz proudly admitted that the head was of his young son. He was initially hesitant to recognize the soldier as he was unsure if he had fought bravely or not. The account attests that the older adult's honor is preponderant over his son's fatherly love and emotion (Poulton, 2003). Poulton further adds similar accounts where brothers are told and reminded by their sisters to fulfill their duty to fight against foreign attempts that encroach Afghan's honor and cultural identity (Poulton, 2003).

A traditional culture that devotes a great deal of importance 
to the aspect of honor is also bound to cherish revenge or vendetta against intentional killing and what is perceived as an insult or dishonorable act against an individual, family, or clan (Anders, 2010). The vendetta or Badal (retaliation) in the Pashto language is applied in the following: "... from intrigue over women, murder of one of the family members or their hamsayas (close neighbors), violation of Badragga (peace delegation), slight personal injury or insult or damage to property. The urge for Badal does not mean that he is savage, bloodthirsty, or devoid of humane qualities. He is kind, affectionate, friendly, and magnanimous and forgives anyone who kills his relatives by mistake, but he will not allow any deliberate murder to go unavenged" (Noorzai, 1998; Khan, 1998).

Another cultural trait of the Afghans that is revered and safeguarded is hospitality and the perceived duty to provide the best possible treatment to a guest. This feature played a major role in the refusal of the Taliban leadership to surrender Osama Bin Laden after he was declared one of the most wanted terrorists following the claim of responsibility for the 9/11 attacks (Jonathan, 2009). To clarify the reason why none of the Taliban soldiers dared to betray Bin Laden and accept the reward of $\$ 25$ million, a Pakistani Army Colonel Muhammad Effendi commented that the high reward money was considered far inferior to the possibility of disgrace that would certainly be earned by anyone who could have betrayed Bin Laden. The life of the possible traitor, and the lives of people from family, clan, and tribe, as Colonel Effendi concluded, “...wouldn't be worth an onion" (Jonathan, 2009).

A similar attitude towards jihad resurfaced in Afghanistan. It was exercised successfully to end the Anglo-Afghan wars (Nawid, 1997) and the Soviet invasion, which attempted to establish a Marxistsocialist state with the help of a weak central government (Cohn \& Goodwin-Gill, 1994). Jihad was used throughout the resistance against the Soviets, mobilizing adults and many underage soldiers, particularly those who found refuge in the neighboring countries (Greenberg Research, Inc., 1999). Greenberg Research mentions that the phenomenon of child combatants - teenagers, to be exact - has been a feature of the Afghan war from the moment the Soviet invasion began. They were recruited with promises of glory for 
their role in the jihad." (Greenberg Research, Inc., 1999).

Once the Soviets were defeated, the mujaheddin soon split into several factions, bitterly fighting among themselves for power. One of the factions that turned to prevail over others is the Taliban, which also rallied support for their authority under the guise of jihad (Shaista \& Youngerman, 2007). The Taliban intentionally recruited younger and underage persons to advance their cause because older fighters who had taken part in the resistance against the Soviets could not get easily convinced that this phase of the fratricidal armed conflict, an armed conflict between Muslims, could be justified as jihad. Thus, the Taliban claimed they were fighting for the true version of Islamic teaching over the corrupt and infidel groups (Barfield, 2010).

Similar to the Taliban in Afghanistan, the Northern Alliance has been reported to use underage fighters both; voluntarily and apathetically by beating them or destroying homes and property (Rohde, 2001; Fonseka, 2001; HRW, 2008; Arai-Takahashi, 2009) to take revenge against the Taliban who had assassinated or severely victimized their family members before and for a host of other causes (Kona,
2007; Takahashi, 2009). According to a survey conducted by M. Bhatia on 237 respondents, the proportion of child fighters under eighteen was $59 \%$, while $49 \%$ of them took part in battles earlier than sixteen (Bhatia, 2008). The United Nations sources also reported that the Northern Alliance had no document or rule that forbids its enlistment and use of juvenile combatants, though the allegations of such practice were faithfully refuted by the then Afghan representative in the United Nations, who was loyal to the Northern Alliance (UNSC, 1999). The Northern Alliance continued to enlist and use children for battle throughout their armed struggle against the Taliban until the collapse of the Taliban regime in late 2001 (www.child-soldiers.org, 2002).

Underage fighters with more extensive combat experience and military prowess have been in elite units with higher recognition among their adult counterparts and civilians. When asked by the reporters and journalists as to the causes for their conscription, the bulk of child soldiers mentioned the lack of economic and education opportunities in the state that had been in armed conflict by then for twenty years (Rohde1, 2001). Another factor connected with the 
conscription of children for combat has been the juxtaposition of the non-state actors to dwellings, towns, and towns where the children were recruited (Stohl, 2002; Chrobok, 2005).

The Taliban have used the same Jihadi strategy for justification of the Taliban insurgency. It was easier after the 9/11 attacks as the newlyformed government of Afghanistan has worked together with some non-Muslim countries to rebuild the country (Arai-Takahashi, 2009). The Taliban controlled certain provinces and districts, particularly religious schools to recruit underage soldiers for their anti-government struggle. As testified by many parents, only in the district of Chadarhara in Kunduz province in 2015, the Taliban recruited one hundred children whom they could easily convince to risk their lives and fight in jihad against infidels what the Taliban consider foreign forces and local aides who betrayed the religion and culture of the Afghans (AraiTakahashi, 2009). Patricia Gossman state: "Farhad joined the Taliban over his father's objections. He is currently a fighter in Commander B's group. His parents and local elders went to the Taliban several times and asked another commander in the group, Commander $\mathrm{C}$, to free
Qari [an honorific title bestowed on someone who has learned to read the Quran] Farhad. Commander C then asked Farhad if he wanted to go back to his family, but as Qari Farhad wanted to stay, Commander $\mathrm{C}$ told his parents and other local elders that "your sons are better Muslims than yourselves. They don't leave jihad" (Gossman, 2016).

The Taliban have repeatedly invoked jihad as their mobilization calls for their supporters to take arms against foreign soldiers in Afghanistan (Weigand, 2017). One of the websites that serve as the mouthpiece of the Taliban renewed calls for jihad against foreign troops and their local supporters who were likened to the pro-communist Soviet supporters during the SovietAfghan war in July 2018, stating that Jihad against American invaders in Afghanistan is a defensive struggle similar to the invasion of infidels that is obligatory as far as Islamic view is concerned. All books of Fiqh (Jurisprudence) agree upon jihad against the invasion of infidels becomes obligatory on every man and woman. It is a clear command of Allah Almighty, and it is a faith of every believer. Those who support American invaders in Afghanistan fight against their religion, country, 
and national values (Mohmand, 2018; Marit \& Sosdal, 2018).

\section{CONCLUSION}

The Afghan and the International legal framework both have prohibited enlistment and use in combat of any person younger than eighteen, but the Afghan culture has not always been adopted the 'straighteighteen' position. Therefore, it can be concluded, however, from the legal perspective, there has not been a permissive stance on persons younger than eighteen to participate in armed struggle. On the other hand, despite the clear position of law on child soldiers in Afghanistan, this conspicuous stance has been continually scorned by the presence of a large number of child soldiers under the Afghan culture, many of whom well below the age of fifteen, in the ranks of various state actors and non-state actors from the outset of the armed struggle to the present day.

As aforesaid, the law, particularly the national one, has always been firmly against child soldiers. However, the severity of the punishment and the enforcement or implementation of the Afghan culture and law have never been executed adequately to keep children away from active participation in combat. Undoubtedly, the discussed cultural factors, including honor, hospitality, and porous unstable institutions, have contributed to the participation of child combatants in Afghan battlegrounds. This only calls for a set of precise recommendations and remedies that would target the root causes to do away with the vile cultural perspective.

The fact is people are not well aware of the legal perspective of Afghanistan on child soldiers as well as they lack a true understanding of Islam as it also prohibits child soldiering. Afghan intellectuals and scholars have to craft some strategy to reach, teach and convince them that child soldiering is an illegal, unacceptable, and intolerable crime whether one looks at it from the perspective of national laws, international legal instruments, or Islamic teaching. The children soldiering must not be considered a matter of ethnic honor and pride as it has disastrous effects on them and society. Consequently, people whose influence stems from culture and relies on culture urgently need to realize these effects and stop the practice of glorifying child soldiers as heroes and thus should break this vicious circle and the multitude of negative effects that it carries with itself. 


\section{REFERENCES}

A Political and Diplomatic History of Afghanistan (1863-1901). (2006). Leiden: Brill.

Achvarina, V., \& Reich, S. F. (2006).

No Place to Hide: Refugees,

Displaced Persons, and the Recruitment of Child Soldiers. International Security, 31(1).

Ahmadi, B., \& Stanikzai, R. (2018, February 15). Retrieved from Redefining masculinity in Afghanistan: https://www.usip. org/sites/default/files/2018-02/ pb243-redefining-masculinityin-afghanistan.pdf

Ahmadi, W. (2008). Modern Persian Literature in Afghanistan Anomalous Visions of History and Form. London: Routledge.

Aisling, P. (2013). Children and International Human Rights Law: The Right of the Child to be Heard. London: Routledge.

Anders, W. (2010). Experiences of Revenge as Reflected in the Contemporary Pashto Short Story. In S. C. Bibb, \& D. Escandell, Best Served Cold: Studies on Revenge. Leiden: Brill.

Andvig, J. C., \& Gates, S. (2010). Recruiting Children For Armed Conflict. In S. Gates, \& S. Reic, Child Soldiers in the Age of
Fractured States. Pittsburgh: University of Pittsburgh Press. Angelo, R. (2005). Afghanistan: A Modern History: Monarchy, Despotism or Democracy: The Problems of Governance in the Muslim Tradition. London: IB Tauris.

Ann, Q., Robinson, C., \& I'Anson, J. (2018). The UNCRC: The Voice of Global Consensus on Children's Rights? Nordic Journal of Human Rights, 36(1), 38-54.

Arai-Takahashi, Y. (2009). Disentangling Legal Quagmires: The Legal Characterisation of the Armed Conflicts in Afghanistan Since 6/7 October 2001 and the Question of Prisoner of War Status. Yearbook of International Humanitarian Law.

Barfield, T. (2010). Afghanistan: A Cultural and Political History. Princeton University Press.

Bhatia, M. (2008). Kunduz, Takhar, and Baghlan: Parties, Strongmen and Shifting Alliances. In M. V. Bhatia, \& M. Sedra, Afghanistan, Arms and Conflict: Armed Groups, Disarmament, and Security in a Post-war Society. London: Routledge. 
Brett, R., \& Specht, I. (2004). Young Soldiers: Why They Choose to Fight. Geneva: International Labour Organization.

Christine, F. (2007). Suicide Attacks in Afghanistan (2001-2007). Kabul: UNAMA.

Chrobok, V. (2005). Demobilizing and Reintegrating Afghanistan's Young Soldiers: A Review and Assessment of Program Planning and Implementation. Afghan Digital Libraries.

Cohn, I., \& Goodwin-Gill, G. S. (1994). Child Soldiers: The Role of Children in Armed Conflict. Oxford University Press.

Dowling, T. C. (2015). Russia at War: From the Mongol Conquest to Afghanistan, Chechnya, and Beyond. California: ABC-CLIO, LLC.

Dupree, L. (1980). Afghanistan. New Jersey: Princeton University Press.

Elisabeth, S., \& Elbert, T. (2010). The Psychological Impact of Child Soldiering. In E. Martz, Trauma Rehabilitation after War and Conflict. New York: Springer.

Ewan, A., \& Hatch, D. N. (1990). The Cultural Basis of Afghan Nationalism. London: Pinter.
Fog, A. (2017). Warlike and Peaceful Societies: The Interaction of Genes and Culture. Cambridge: Open Book Publishers.

Fonseka, B. (2001). The Protection of Child Soldiers in International Law. Asia Pacific Journal on Human Rights and the Law, 2(2).

Gossman, P. (2016, February 17). Afghanistan: Taliban Child Soldier Recruitment Surges. Retrieved from Human Rights Watch: https://www.hrw.org/ news/2016/02/17/afghanistantaliban-child-soldierrecruitment-surges

Greenberg Research, Inc. (1999). People on War Project, The People on War Report: ICRC Worldwide Consultation on the Rules of War. International Committee of the Red Cross, 1-31.

Hassan, K. M. (2006). A Political and Diplomatic History of Afghanistan, 1863-1901. Leiden: Brill.

HRW. (2008). Coercion and Intimidation of Child Soldiers to Participate in Violence. New York: Human Rights Watch.

Jonathan, H. (2009). The Pashtun Cultural Code: Pashtunwali. 
Australian Defence Force Journal.

Khan, S. J. (1998). The Religious Leadership of Pashtuns. American University.

Kona, S. (2007). Child Soldiers in Afghanistan. IPCS Special Report.

Lee, A.-J. (2009). Understanding and Addressing the Phenomenon of 'Child Soldiers'. Oxford: The Refugee Studies Center.

M., R. D. (2015). Child soldiers in the Western imagination: From Patriots to Victims. New Jersey: Rutgers University Press.

Marit, S., \& Sørsdal, L. M. (2018). The Child's Best Interest Principle across Child Protection Jurisdictions. In A. Falch-Eriksen, \& E. BackeHansen, Human Rights in Child Protection. Palgrave Macmillan.

Mohmand, K. A. (2018, July 9). Statement of Islamic Emirate Regarding Conference of Religious Scholars in Saudi Arabia. https:// $w w w . v e t e r a n s t o d a y . c o m$. Retrieved from https://www. veteranstoday.com/2018/07/10/ afghanistan-statement-ofislamic-emirate-regardingconference-of-religiousscholars-in-saudi-arabia
Monsutti, A. (2013). Anthropologizing Afghanistan: Colonial and Postcolonial Encounters. Annual Review of Anthropology.

Nawid, S. (1997). The State, The Clergy, and British Imperial Policy in Afghanistan During the 19th and Early 20th Centuries. International Journal of Middle East Studies, 29(4).

Norway: Landinfo. (2017). Afghanistan: Recruitment to Taliban. Genève: www. refworld.org.

Noorzai, R. (1998). Communication and Development in Afghanistan a History of Reforms and Resistance. Athens: The Scripps College of Communication of Ohio University.

Poulton, R. E. (2003). Honour, Guns and JihadImproving Childhood and Communications in Afghanistan would Promote peace. Conflict, Security \& Development, 3(3).

Qanet, G. M., \& Jan, M. N. (2019). Madrasas and Recruitment of Child Soldiers: The Scenario in Afghanistan. International Journal of Recent Technology and Engineering (IJRTE), 8( 1C2). 
Qanet1, G. M., \& Jan1, M. N. (2019). Recruitment of Child Soldiers by Rebels in Afghanistan: The Role of Pakistani Madrasas. Journal of Islamic Law Review, 15(1).

Rohde, D. (2001, October 2). Child Soldiers Filling Ranks in Civil War. New York Times.

Rohde1, D. (2001, October 2).

A Nation Challenged: The Soldiers; 12-Year-Olds Take Up Arms Against Taliban. New York Times.

Saikal, A. (2004). Modern Afghanistan: A History of Struggle and Survival. London: IB Tauris \& Co. Ltd.

Shaista, W., \& Youngerman, B. (2007). A Brief History of Afghanistan. New York: Infobase Publishing.

Steinl, L. (2017). Child Soldiers as Agents of War and Peace: A Restorative Transitional Justice Approach to Accountability for Crimes under International Law. Berlin: Springer.

Stohl, R. (2002). Targeting Children: Small Arms and Children in Conflict. The Brown Journal of World Affairs, 9(1).

UNSC. (1999). The Situation in Afghanistan and Its Implications for International Peace and
Security. UN Security Council: New York.

Weigand, F. (2017). Afghanistan's Taliban-Legitimate Jihadists or Coercive Extremists? Journal of Intervention and State Building, 11(3), 363-367.

William, B. (2012). Lessons from Afghanistan's History for the Current Transition and Beyond. Washington, DC: United States Institute of Peace.

William, M. (2010). Afghanistan: An Historical and Geographical Appraisal. International Review of the Red Cross, 859-876.

www.child-soldiers.org. (2002). Coalition to Stop the Use of Child Soldiers. Retrieved from https://www.child-soldiers.org Zyck, S. A. (2011). But I'm a Man: The Imposition of Childhood on and Denial of Identity and Economic Opportunity to Afghanistan's Child Soldiers. In A. Özerdem, \& S. Podder, Child Soldiers: From Recruitment to Reintegration. London: Palgrave Macmillan. 